\title{
Multiple disadvantage of older migrants and native Dutch older adults in deprived neighbourhoods in Amsterdam, the Netherlands: a life course perspective
}

\author{
Sabine van der Greft · Joos Droogleever Fortuijn
}

Published online: 7 December 2015

(C) The Author(s) 2015. This article is published with open access at Springerlink.com

\begin{abstract}
It is commonly suggested that older nonWestern migrants have a higher risk of experiencing multiple forms of disadvantage than native older adults. However, few researchers have studied the life situation and urban conditions of older migrants in relation to each other and in comparison to native older adults with a similar socioeconomic status. This paper investigates whether different groups of older nonWestern migrants (of Surinamese, Moroccan and Turkish origin) in deprived neighbourhoods in Amsterdam experience similar or different levels of multiple disadvantage compared to socioeconomically similar native Dutch older residents living in the same neighbourhoods, and explores how multiple disadvantage can be explained in relation to life and residential histories and neighbourhood changes. Analysis of 85 in-depth interviews indicates that all categories of lowincome older adults experienced certain levels of disadvantage, although they evaluated their circumstances using different frames of reference. Regarding health, both native-born and migrant older people experienced chronic illness. However, the results of this study suggest that those in the latter group (especially Moroccans and Turks) experienced health problems and related functional limitations at a
\end{abstract}

S. van der Greft $(\bowtie) \cdot$ J. Droogleever Fortuijn Department of Geography, Planning and International Development Studies, University of Amsterdam, Amsterdam, The Netherlands e-mail: s.vandergreft@uva.nl younger age. Native Dutch older adults were somewhat better off with respect to the availability of household resources, but compared to older nonWestern migrants were more likely to experience the negative effects of neighbourhood deprivation. In summary, this study refines common assertions that older migrants are more disadvantaged than native older adults. Differences in experiences of advantage and disadvantage have their origin in differences in life and residential histories and neighbourhood change.

Keywords Ageing - Disadvantage - Ethnicity - Life course $\cdot$ Migrants $\cdot$ Neighbourhood

\section{Introduction}

Population ageing and international migration, combined with increasing urbanisation, are major societal trends across the world. As cities grow, the urban population is ageing and becoming more ethnically diverse (ERA-AGE 2007; United Nations 2008; WHO 2007). In policy discourse, the discussion of ageing and (some flows of) migration has generally been quite pessimistic. Older adults and unskilled, low-earning migrants are typically characterised as dependent and unproductive, and hence labelled as net beneficiaries of the welfare state (Crampton 2009; Razin and Sadka 2000; Warnes 1990). Although the concept of 'successful ageing' and related terms like 'optimal ageing' 
and 'age-friendliness' reflect a changing view on ageing in Western societies, with a focus on high levels of functioning and well-being rather than vulnerability (Baltes and Baltes 1990; Rowe and Kahn 1998; WHO 2007), gerontological research shows that loss and the risk of dependency are inextricably bound to human ageing (Deeg 2002; Van Tilburg 2005). Consequently, it is likely that ageing, international migration and continued urbanisation will entail an increasing share of vulnerable older people in cities.

Among the most vulnerable categories of older people in many cities in Western Europe are nonWestern migrants (Scharf et al. 2005a, b; Warnes et al. 2004). A large number of non-Western people migrated during the 20th century, either from (former) colonies or from guest worker recruitment countries like Morocco and Turkey (Hansen 2003; Musterd and Van Kempen 2009; Warnes and Williams 2006). In a study on older migrants in Europe, Warnes et al. (2004: 312) argue that '[...] in comparison to the host populations, they [i.e. older labour migrants] have had a lifetime of disadvantage and deprivation, including poor health care and housing conditions, few opportunities to learn the local language, and very often the insults of cultural and racial discrimination'. According to theories of cumulative disadvantage, early disadvantages may accumulate over time and across multiple dimensions. It is also known that multiple forms of disadvantage may occur simultaneously in one individual (Dannefer 1987; Scharf and Bartlam 2006; Soldo and Longino 1988; Van der Meer et al. 2008a). Subsequently, researchers have established that the experience of disadvantage in old age can be understood as the outcome of a cumulative process that accrues over the life course, shaped by individual circumstances (such as gender, ethnicity or social class) and constrained by societal structures in the country of residence (e.g. economy, political and legal systems) (Bernard and Scharf 2007; Dannefer and Uhlenberg 1999; O'Rand 2006; Street 2007; Warnes et al. 2004).

Residential history in a person's country of origin as well as within the host society is also important for understanding the process of cumulative disadvantage (Burholt 2004). Older adults may not only have changed neighbourhoods in the course of their lives, but their residential environment is also subject to change (Burns et al. 2012; Deeg and Thomése 2005; Phillipson 2007). Older people living in deprived urban neighbourhoods in particular often face the deterioration of physical structures, rapid turnover of buildings and high levels of residential mobility in the course of their lives. While urban changes can be advantageous for some categories of older adults (i.e. ethnic services for minority groups, relatively cheap housing, the presence of people with a similar background), it is also important to acknowledge that they may have adverse consequences for others (i.e. the destruction of familiar landscapes and inadequate local amenities) (Becker 2003; Buffel and Phillipson 2011; Scharf et al. 2001). Consequently, the study of multiple disadvantage in combination with ageing requires a life history approach that takes into account residential history as well as neighbourhood changes in older people's residential environment.

In recent years, researchers have called attention to the manifold disadvantages that some categories of older migrants in Western Europe may face (Warnes and Williams 2006); however, most studies have addressed the various aspects of disadvantage only in isolation. There is a need for research that sheds light on how the multiple disadvantages experienced by older migrants can be understood in relation to one another. Much more also needs to be learned about how disadvantages experienced by older non-Western migrants can be compared to those of their native counterparts. Older non-Western migrants are generally considered more disadvantaged than native older adults (Warnes et al. 2004), but since there are commonly huge socioeconomic differences, a comparison only makes sense when studying older people with a similar socioeconomic position. Ultimately, the life and neighbourhood experiences of older nonWestern migrants might be rather similar (or even more favourable) to those of socioeconomically similar groups of native older residents living in deprived neighbourhoods (Van der Greft et al. 2014).

Drawing on qualitative data derived from an empirical study conducted in deprived urban areas in Amsterdam, the Netherlands, this paper addresses the following research question:

What are the differences in experiences of multiple disadvantage among older non-Western migrants (of Surinamese, Moroccan and Turkish origin) and between older non-Western migrants and socioeconomically similar native Dutch older adults living in deprived neighbourhoods 
in Amsterdam, and how can this be understood in relation to their life and residential histories and neighbourhood changes?

The remainder of this paper is divided into four sections. In the first section, we elaborate on the various dimensions that constitute the concept of multiple disadvantage. This is followed by a discussion of the Dutch institutional context and a methodology section. In the third section, we provide the main findings. We conclude with a discussion of the empirical results.

\section{Literature review}

Multiple disadvantage is inherently a multidimensional and cumulative concept that can be defined as the aggregate of all the factors that together increase the risk of vulnerability. Disadvantages do not automatically lead to a vulnerable position; the extent to which they have negative consequences depends on the bearing capacity of the individual. This implies that the advantages (or competencies) that older adults bring to later life have the innate potential to mediate the negative effects of certain disadvantages (Deeg 2002; Grundy 2006; Van der Meer et al. 2008a; Verhoeven et al. 2011). Adversely, disadvantages experienced in one area may accelerate the rate of decline in others (Soldo and Longino 1988). Vulnerability reflects the outcome of a disturbed balance between advantages and disadvantages. In the following section, we will address three key areas of advantage and disadvantage in more detail, with the aim of making explicit key assumptions about how life and residential history, as well as neighbourhood changes, may shape older people's experiences in later life.

Vulnerability at the individual level: personal functional dependency

Personal health status is a useful starting point for studying dimensions of disadvantage among older adults. The key question to be answered is whether health problems have behavioural consequences in terms of functional limitations (Van der Meer et al. 2008a). Functional limitations relate directly to an individual's ability to perform the daily activities required for personal self-care and independent functioning, such as bathing, going to the toilet, preparing meals, walking, shopping and doing housework (Katz 1983; Soldo and Longino 1988).

Multiple personal, social, economic and environmental factors influence the health status of a person (Clarke and Nieuwenhuijsen 2009; WHO 2014). Research findings demonstrate that the risk of poor health and related functional dependency increases with age (Baltes and Smith 2003). It is also known that older adults with lower incomes, lower education and a background in less skilled occupations commonly experience worse health and die earlier (Bulatao and Anderson 2004; Friscella and Williams Fiscella and Williams 2004; Grundy 2006; Knoops and Van den Brakel 2010). Socioeconomic status plays an important role in explaining ethnic disparities in health; however, some studies have found that differences between ethnic groups remain, even for groups with a similar socioeconomic position (Denktaş 2011; Pudaric et al. 1998; Schellingerhout 2004). Health conditions that emerge later in adulthood can often be traced back to earlier life stages; thus life conditions, lifestyle, health status and access to medical care in the past have consequences for outcomes in old age (Deeg 2002; Fiscella and Williams 2004; Reinprecht 2006).

Vulnerability at the household level: resources

The second dimension of multiple disadvantage refers to resources at the household level. These resources can be used to compensate for the potential negative effects of functional limitations at the individual level. An adequate income and the presence of other household members are generally seen as the most important resources, because they are expected to provide access to formal and informal care (De Jong Gierveld et al. 2002; Van der Meer et al. 2008a). Household income allows older adults to alter their environment or adjust to difficulties through paid support (domestic help, a paid caregiver, home improvements, a mobility scooter, etc.) (Van der Meer et al. 2008a). Current financial resources are accumulated during the life course and may have their origin in employment history, education and skills acquired in the past (Grundy 2006; Warnes et al. 2004). In general, older people's assets and income diminish after retirement. Because of limited 
opportunities for paid work in later life, incomes in old age are largely dependent on the transfer of resources (e.g. social security benefits such as state pensions, transfers from relatives) and on asset accumulation earlier in life (e.g. private pensions, savings). As a result, older people's financial position is highly dependent on decisions made by others and is vulnerable to macro-economic circumstances and policy changes over which they have no direct control (Grundy 2006). For older migrants in particular, linguistic skills and knowledge of the institutional context in the host society are also crucial (Warnes et al. 2004). According to Grundy (2006: 108), 'it is not just the resources available to an individual that are important, but their ability to draw on them'.

Although the living standards of older adults in most Western countries have been rising in recent years, Naegele and Walker (2008: 148) emphasise that 'poverty in old age is still a continuing problem in the EU [European Union] but only among a significant minority of older people'. Older adults who are especially at risk of poverty are very old adults, older women, particularly widows, older people with a background in low-paid occupations or who have been incapacitated or unemployed in the course of their lives, and some groups of older migrants, including older labour migrants (Arber 2006; Grundy 2006; Warnes et al. 2004; Zaidi 2010). In this respect, it is also important to recognise that financial needs may differ across households at a similar level of income. Chronic disability and differences in household size, composition and related household expenses are likely to have consequences for older people's living standards (Whelan et al. 2007).

Marital status and household composition are pivotal to older people's household income and expenditures, but also have a crucial impact on their access to informal care (Arber 2006). Household members, partners in particular, constitute an important source of informal support for older adults with functional limitations, especially older men (Schenk et al. 2013; Soldo and Longino 1988). At the same time, several researchers indicate that not all multiple person households are equally supportive (Waite and Hugfies 1999). After all, support does not flow in only one direction; it is not only the older adult who receives care, but demands for support from other household members must also be taken into account (De Jong Gierveld et al. 2002).
Environmental context: quality

of the neighbourhood

The third dimension of multiple disadvantage concerns the adequacy of the physical and social environment in which an older adult lives, in terms of considering whether or not it provides the compensatory factors that may mitigate the negative effects of functional limitations at the individual level and/or those due to lack of household resources (Van der Meer et al. 2008a, b). Lawton and Nahemow's ecological model of ageing (1973) offers a useful framework with which to describe and explain the relationship between individual competency and the environment, focusing on the fit between the two. An optimal fit occurs when a person's competency is paired with the appropriate degree of environmental demands and opportunities. A person-environment mismatch is expected to result in maladaptive behaviour and low levels of functioning. Furthermore, Lawton suggests in his Environmental Docility Hypothesis that as a person's competence declines, the impact of environmental factors on the individual increases (Lawton 1982). In contrast, his Environmental Proactivity Hypothesis proposes that an increase in personal competence enhances a person's ability to choose, create or shape his/her environment according to his/her own needs and preferences (Lawton 1990).

According to Soldo and Longino (1988: 116), 'Improving the quality of the social and economic environment in which ageing occurs may not only improve the quality of life of the already frail, but may also retard rates of transition from the well to the disabled state'. Driven by the World Health Organisation's (WHO) Age-friendly Environments Programme, there has been increased interest in making communities more 'age-friendly' (Buffel et al. 2012). The WHO (2007: 1) defines age-friendly cities as those encouraging 'active ageing by optimising opportunities for health, participation and security in order to enhance quality of life as people age'. By providing safe places with adequate housing and infrastructure, local access to shops and neighbourhood facilities, helpful neighbours and a warm social climate, supportive neighbourhoods enable older adults to retain independence and well-being for longer. In contrast, deprived neighbourhoods are less likely to provide the conditions in accordance with the 
age-friendly cities principle (Beard and Petitot 2010; Clarke and Nieuwenhuijsen 2009; Scharf et al. 2001; Van der Meer et al. 2008a).

Research in Britain demonstrates that older adults in deprived urban neighbourhoods, and (some groups of) older migrants in particular, are at risk of being affected by multiple forms of disadvantage and exclusion in terms of material resources, social relations, civic activities and basic neighbourhood services (Scharf et al. 2004, 2005a, b). Others have reported on the potentially harmful living conditions of older migrants living in inner city neighbourhoods, especially with respect to housing quality, social deprivation and crime (Becker 2003; Nitsche and Suijker 2003; Van der Greft et al. 2014). Exclusionary processes within the neighbourhood can be aggravated by urban change (Buffel et al. 2013; Scharf et al. 2001). This applies in particular to neighbourhoods that have undergone stages of physical decline, loss of amenities and certain types of social change linked to mounting criminality and high residential mobility. Various forms of exclusion may, however, also occur in neighbourhoods undergoing processes of gentrification (Burns et al. 2012; Lager et al. 2013; Phillipson 2010). Despite feeling marginalised or aliened by changes in their communities, disadvantaged older adults are rarely in a position to leave (Phillipson 2007).

At the same time, research also suggests that the advantages of living in inner city neighbourhoods needs to be taken into account. For older migrants in particular, relatively cheap housing, services for minority groups and the presence of children, family members and acquaintances with a similar ethnic and cultural background are highly attractive inner city potentials (Becker 2003; Buffel and Phillipson 2011; Buffel et al. 2012; Nitsche and Suijker 2003; Scharf et al. 2001). Furthermore, researchers in the United States have found some indications for a positive relationship between living in an area with a higher proportion of residents of a similar (racial) origin (i.e. Blacks) and self-rated health among older people (Robert and Ruel 2006).

\section{The Dutch institutional context}

As mentioned, an individual's position in later life is (at least to some extent) shaped by the institutional context in his/her country of residence. This might hold especially true for older adults living in the highly regulated context of the Netherlands. From a global comparative perspective, the Dutch welfare state has traditionally been characterised by its comprehensiveness and can still be regarded as generous. As in other Western European welfare states, government interventions affect various domains of economic and social life, including health, work, income and housing (Van Oorschot 2006). This has resulted in relatively moderate levels of spatial segregation and income inequality (van Amersfoort and Cortie 1996; Musterd and Deurloo 2002).

Health care in the Netherlands is covered by a compulsory semi-public solidaristic health insurance scheme (Daley et al. 2013). An extended social security system provides a high degree of financial security to protect citizens from the financial consequences of sickness, occupational disability, unemployment, the death of a partner or parent and old age. People who have reached the state pension age receive a basic pension, the amount of which depends on their length of residence in the Netherlands (European Union 2013; Zorlu 2011). The Dutch housing market is also highly regulated (Musterd and van Kempen 2007). Interventions include rigid rent control, the provision of a large social housing sector and housing allowances for tenants. In general, there are long waiting lists to obtain social rented dwellings, especially in areas with a tight market. As a result, older adults may not be able to find their desired dwelling in the neighbourhood they prefer (Kullberg 1997; Vandevyvere and Zenthöfer 2012; Van Oorschot 2006).

All of the aforementioned dimensions have, however, been subject to significant changes over the past decades, reflecting the Dutch transition from a rather comprehensive welfare state towards a 'participation society' in which citizens are expected to take responsibility for their own future as well as for other vulnerable citizens. One aspect of this concerns the deinstitutionalisation of elderly care by encouraging older adults to remain independent and in their own homes for as long as possible, with the help of family members, friends and neighbours. Because of this, residential environment and local community are becoming more important in determining how well people age.

\section{Study population and area}

The study population of this paper includes the three largest groups of non-Western older adults $(55+)$ in 
the Netherlands-Surinamese (66,216), Turks $(41,328)$ and Moroccans $(39,442)$ - and a reference group of native Dutch older people $(4,366,460)$ (Statistics Netherlands 2014, authors' selection). Older non-Western migrants in the Netherlands show a high degree of heterogeneity in terms of migration history, education and knowledge of the Dutch language. Although there has been a longer tradition of Surinamese migrating to the Netherlands, the majority of Surinamese older migrants settled in the Netherlands for economic and political reasons shortly before and after the independence of Surinam in 1975. Many Surinamese migrants came to the Netherlands for higher education or work, and upon arrival they were relatively well educated, rather focused on Dutch society and had a good command of the Dutch language. This is in stark contrast to Turkish and Moroccan older migrants: the men settled in the Netherlands predominantly in the 1960s and early 1970s as labour migrants, while the women came later through processes of family reunification or family formation. In general, both Turkish and Moroccan older migrants came from regions experiencing severe agricultural decline and had received limited education. Upon arrival in the Netherlands, they had no command of the Dutch language and generally entered low-skilled and low-paid jobs (Dagevos 2001; Schellingerhout 2004).

Today, older non-Western migrants tend to live in the large cities, and within these cities, in deprived neighbourhoods (Nitsche and Suijker 2003). In this paper, we will focus on the capital city of the Netherlands, Amsterdam, and specifically on neighbourhoods with an overrepresentation of older nonWestern migrants. Of the 790,044 people in Amsterdam in 2012, there were 13,444 Surinamese, 7974 Moroccan, 4400 Turkish and 112,354 native Dutch 55+ residents (Stadsmonitor Amsterdam, Dienst Onderzoek en Statistiek, own calculation). The Moroccan and Turkish older adults recruited into the study were mainly located in the Indische buurt and the Kolenkit neighbourhoods. The Surinamese older adults predominantly lived in the Bijlmer (EGK neighbourhood) and the Indische buurt. The study areas were selected because research had shown an overrepresentation of older non-Western migrants in each of these neighbourhoods (Van der Greft et al. 2014). Based on our review of the literature, we hypothesise that neighbourhood ethnic composition may affect older people's neighbourhood experiences with regard to the proximity of ethnic services and members of a similar ethnic and cultural background. Native Dutch older adults were also selected in the abovementioned neighbourhoods, but in no areas were they over-represented relative to the city-wide figure. All research areas were ranked in the 2007 list of 40 most deprived neighbourhoods in the Netherlands; the Kolenkit was even ranked as the number one 'problem district' by the national government (Ministerie VROM/WWI 2009). ${ }^{1}$

\section{Data and methodology}

The findings presented in this paper are based on 85 semi-structured interviews: 29 interviews with native Dutch, 16 interviews with Moroccan, 21 interviews with Surinamese and 19 interviews with Turkish older adults. Older individuals living in institutions were excluded from this study. Older adults with (mild) cognitive disorders or (mild) memory loss were included; however, this was only the case if their capability to give informed consent and tell their life and residential experiences was not undermined. The interviews were conducted between December 2012 and December 2013 and had an average length of nearly $2 \mathrm{~h}$. It is known from previous research that gaining access to older non-Western migrants with a low income in the Netherlands is a difficult process and non-response rates are usually high (Deding et al. 2008; Lamers et al. 1993; Schmeets 2004). We therefore used a wide variety of recruitment strategies, which ranged from visiting ethnic community associations, local community centres or meeting places (including houses of worship) and attending meetings, to approaching prospective candidates on the street, knocking on people's doors and providing research incentives in the form of gift certificates for the amount of 10 Euros.

\footnotetext{
$\overline{1}$ The selected neighbourhoods are characterised by a range of socioeconomic deprivation and liveability problems. We need to point out, however, that in the Dutch context, levels of neighbourhood deprivation are relatively low compared to cities in Anglo-Saxon countries.
} 
Table 1 Characteristics of the interviewees

\begin{tabular}{|c|c|c|c|c|}
\hline & Moroccans & Surinamese & Turks & $\begin{array}{l}\text { Native } \\
\text { Dutch }\end{array}$ \\
\hline \multicolumn{5}{|l|}{ Age } \\
\hline$<60$ & 9 & 2 & 6 & 0 \\
\hline $60-70$ & 7 & 11 & 11 & 5 \\
\hline $71-80$ & 0 & 5 & 2 & 13 \\
\hline$>80$ & 0 & 3 & 0 & 11 \\
\hline \multicolumn{5}{|l|}{ Sex } \\
\hline Male & 7 & 4 & 11 & 9 \\
\hline Female & 9 & 17 & 8 & 20 \\
\hline \multicolumn{5}{|l|}{ Income } \\
\hline Low & 15 & 15 & 17 & 18 \\
\hline Low to modal & 0 & 5 & 1 & 8 \\
\hline$>$ Modal & 1 & 1 & 1 & 1 \\
\hline Unknown & 0 & 0 & 0 & 2 \\
\hline \multicolumn{5}{|l|}{ Marital status } \\
\hline Married & 10 & 2 & 16 & 6 \\
\hline Widowed & 4 & 3 & 2 & 13 \\
\hline Divorced & 2 & 9 & 1 & 6 \\
\hline Never married & 0 & 7 & 0 & 4 \\
\hline \multicolumn{5}{|l|}{ Household } \\
\hline Alone & 4 & 16 & 1 & 24 \\
\hline With partner & 1 & 0 & 9 & 5 \\
\hline $\begin{array}{l}\text { With partner } \\
\text { and children }\end{array}$ & 7 & 2 & 7 & 0 \\
\hline Other & 4 & 3 & 2 & 0 \\
\hline \multicolumn{5}{|l|}{$\begin{array}{l}\text { Chronic } \\
\text { conditions }\end{array}$} \\
\hline Yes & 13 & 18 & 17 & 27 \\
\hline No & 3 & 3 & 2 & 2 \\
\hline \multicolumn{5}{|l|}{ Mobility: car } \\
\hline Yes & 6 & 1 & 9 & 12 \\
\hline No & 10 & 20 & 10 & 17 \\
\hline \multicolumn{5}{|l|}{ Social housing } \\
\hline Yes & 16 & 20 & 19 & 28 \\
\hline No & 0 & 1 & 0 & 1 \\
\hline \multicolumn{5}{|l|}{$\begin{array}{l}\text { Housing } \\
\text { accessibility: } \\
\text { stairs }\end{array}$} \\
\hline Yes & 10 & 7 & 12 & 13 \\
\hline No & 6 & 14 & 7 & 16 \\
\hline
\end{tabular}

Table 1 demonstrates that we succeeded in finding older adults of native Dutch, Surinamese, Moroccan and Turkish origin with low or low to modal household income. ${ }^{2}$ All interviewees (except one) were 55 years or older. Although the retirement age in the Netherlands is 65 years, people with a low income, people living in deprived neighbourhoods and nonWestern migrants in particular are more vulnerable and feel old at a relatively young age (Schellingerhout 2004). We therefore included individuals aged 55 years and older in this study. The majority of the interviewees had a low income. All interviewees, except two, were living in a house in the social sector. The research group reflects the demographic composition of the older population in Amsterdam. Consequently, the native Dutch-and to a lesser extent the Surinamese-were older, and therefore more often female, widowed and living alone, than the Turkish and Moroccan interviewees. These age differences might raise concerns regarding the sample of research participants. We analysed the various dimensions of multiple disadvantage separately for the interviewees aged 60-70 years. When adjusted for age, the results were in general very similar to those found for the research group as a whole.

The recruitment strategy had some limitations. We could not prevent the interviewing of people belonging to the same social networks and it is likely that the frail and most socially isolated older adults are underrepresented. Furthermore, not all interviewees were living in the selected neighbourhoods; some lived in adjacent areas. Because these areas were often considered part of the respective research locations, this has no major implications for the interpretation of the main findings. Interviews with Surinamese and

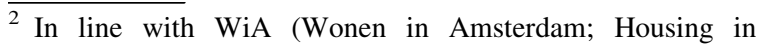
Amsterdam) data, we defined low household income as earnings below $€ 1330$ net per month for single households, and below $€ 1680$ per month for multiple person households; we defined low to modal incomes as between $€ 1330 / 1680$ and $€ 1980$ net per month (Dignum and Yin Kan 2014). Household incomes do not include additional assistance, such as health benefits, rent subsidies, child support or asset accumulation (private savings, property ownership, etc.). Many older adults did not count the income of their children as household income. Several interviewees were reluctant to answer questions about their income, either because of lack of knowledge or because the topic touched upon sensitive aspects of the interviewee's circumstances (i.e. social security affiliations). The findings hint at the suggestion that Moroccans and Turks may have given socially desirable answers, especially with respect to the earnings of household members other than their partner. As a consequence, the income of children was not included in the study.
} 
native Dutch older residents were undertaken by the first author. Interviews with Turkish and Moroccan older adults were conducted by trained interviewers recruited from these ethnic groups, in the language of the interviewees' choice. For all categories of older adults, a similar topic list was used, which covered issues regarding their health status, income position, employment history, household composition, housing situation, quality of the neighbourhood, residential history and neighbourhood changes.

All interviews were audiotaped and transcribed verbatim. The Moroccan and Turkish interviews were translated into Dutch where necessary. Then the transcriptions were coded thematically using the computer software program Atlas.ti. Once all interviews had been coded, we summarised the data in a matrix for each theme and by respondent (Bryman 2008). This allowed us to easily read across the whole dataset without losing the life course perspective.

\section{Empirical findings 1: personal functional dependency}

The majority of interviewees experienced one or more chronic health problems, including respiratory, circulatory and musculoskeletal disorders such as heart disease, hypertension, diabetes and arthritis. Some older adults mentioned that they were suffering from mental health problems such as depressive disorders, chronic stress or cognitive decline and memory problems. One native Dutch male had been diagnosed with Alzheimer's disease, but was still able to narrate his experiences.

According to the literature, an older person's current health status is supposed to have its origin in the life conditions, lifestyle, health status and access to medical care over the person's life course, as well as in the type of job he/she had. Our empirical findings appeal to a similar line of reasoning. Several Moroccan and Turkish older adults reported that they had been exposed to physically demanding or stressful working conditions, which have presumably had adverse effects on their health. The response of a 57-year-old Moroccan woman is typical:

I have pain in my shoulders, knee, neck, and back. This is caused by years of working in the cleaning industry.
The link between employment history and current health status was less manifest in the narratives of Surinamese and native Dutch older adults, though some older people's accounts of their working lives, especially those of former health care, catering and cleaning services workers, contained reference to the physically demanding working conditions that they had faced.

In individual cases, physical or mental health problems appeared to be caused or exacerbated by traumatic life events; for example, the loss of a parent or partner through divorce or death. A 56-year-old Surinamese man explained how the difficulties he faced in coping with the death of his mother led to alcohol abuse and subsequent pancreatic disease. Some female interviewees had been the victim of physical violence by their partners at some point in their lifetime. A 56-year-old Surinamese woman had lost her job and experienced various health problems and functional limitations after being involved in an abusive relationship:

After that [divorce] all problems started. I didn't care for my health. This resulted in several health problems: irritable bowel syndrome, Besnier-Boeck disease, respiratory problems... Because of this, I get tired very easily (...). Look, I had surgery on my hands. These abuses are caused by my ex. I never got back strong hands.

Not all health problems lead to functional limitations, however, and not all functional limitations result in negative health related self-perceptions. Conditions become problematic when pain and discomfort interfere with everyday activities. Around half of the interviewees were identified as having at least some difficulties in carrying out daily tasks; however, most of them only needed help with heavy household chores such as vacuuming, bathroom cleaning or grocery shopping. Only a few needed help with personal care. Non-Western older migrants required assistance with day-to-day tasks slightly less often than native Dutch interviewees. Many older adults with functional limitations had adapted their activities accordingly; several interviewees prided themselves on still being able to perform specific tasks in daily life on their own. Others put their deteriorated health into perspective by stating that they had relatively good health for someone of their age: 
It started with my leg. I should not complain, because I was able to cycle until the age of 84 . Well, many people cannot cycle. I am physically healthy. I only have high blood pressure, but I have pills for that. And for 10 years I have had spots in front of my eyes. (...) And I cannot lift my leg; I drag it a bit. That's why I walk with a Zimmer frame, but I can handle it. For my age, I have no complaints.

(90-year-old Dutch woman; id83)

Growing old and the loss of physical and cognitive functions were generally perceived as inextricably linked processes. Fear of dependence, impending death and the loss of family and friends caused strong negative feelings. Additionally, Moroccan and Turkish interviewees referred to their loss of hopes and dreams for the future. Positive aspects of ageing were also reported, however, such as feelings of pride, being respected, being able to do what they want and enjoying wisdom and knowledge. Compared to native Dutch older adults, Moroccan, Turkish and some of the Surinamese older migrants strongly believed that God had control over their health. Turkish interviewees experienced ageing more negatively than the other categories of older adults. This finding is consistent with previous research studying perceptions of ageing among Turkish and Surinamese older adults and could partly be explained by migration history, religion, mastery of the Dutch language, having proactive coping skills and cultural attitudes to age and ageing (Bode et al. 2007; Dijkstra 2006).

Furthermore, empirical evidence indicates that living in a foreign country can increase the risk of being affected by specific health and care access problems. This appeared to be particularly true for Moroccan and Turkish older adults. Several interviewees, like the 61-year-old Moroccan woman below, reported that their health status improved when visiting their country of birth:

When I am there, all my symptoms spontaneously disappear. I am reunited with my parents and everything goes well. Back in the Netherlands, my health goes downhill once again and I suffer from the same health problems as before.
The example above also points to the possibility of decreased emotional well-being as a result of being separated from family. Additionally, some Moroccan and Turkish interviewees reported obstacles to receiving health care in the Netherlands due to a limited command of the Dutch language and structural barriers, such as a poor understanding of the Dutch health care system, a lack of cultural competence among health care providers, underinsurance and financial hardship:

We only have a basic health insurance, so we only have access to a general practitioner and the hospital, but we cannot use other things, like therapy or something. You have immediately to pay your mandatory excess. We don't have access to the care we need. I have diabetes and my wife has heart disease, so we need to go. But we cannot receive additional care, because you have to pay a personal contribution. That is 700 Euros for the both of us.

(61-year-old Moroccan man; id58)

The results support the hypothesis that non-Western migrants, especially Moroccans and Turks, experience health problems and related functional dependencies at a relatively young age. A comparison of these groups in the age category $60-70$ years tentatively points in the same direction. The analysis suggests that the differences in functional dependency have their origin in differences in life and residential histories.

\section{Empirical findings 2: household resources}

The pathways that have led to low income among different groups of older adults are in many ways comparable. Having a low income in later life can most commonly be linked to a person's lifetime employment history. Low-income older adults generally have incomplete career paths due to unemployment, occupational incapacity, early retirement and the limited labour market participation of women; alternately, many spent most of their working lives in (low-paid) occupations with no or limited pension rights (including self-employment). Only a few people interviewed (had) continued to work after (pre-)retirement. Although financial disadvantage among socioeconomically similar categories of older adults was largely 
generated in similar ways, one crucial difference was the fact that the older migrants had generally settled in the Netherlands as adults and therefore had had a limited time span in which to build up entitlements to occupational, personal and state retirement pensions in particular. A 65-year-old Turkish man compared his financial position to native Dutch older adults with a full state pension:

The Dutch have lived here longer than I have, so they built up more pension rights than me. That makes a big difference. Maybe they have five or ten Euros a month more to spend, but that carries weight. The Dutch might have saved in good times or have accumulated assets. We came here to work and intended to go back after five years. We have never returned and were not able to set aside money.

Income inequality is nevertheless only part of the story. A number of narratives revealed that differences in expenditure are relevant as well. Compared to native Dutch older adults, migrant older people (Moroccans and Turks in particular) commonly have more expenses; for example, for social obligations with a large number of guests, such as weddings, and for travel, when they visit their country of origin or make the pilgrimage to Mecca. This was manifest in the response of a 61-year-old Moroccan woman:

If I do not have the money, I borrow cash from acquaintances or neighbours to visit my parents each winter and summer. With 733 Euros a month you cannot travel to Morocco and pay your bills.

Although it has been suggested that older migrants are not always aware of their welfare entitlements due to social barriers, language problems and limited knowledge of benefits (Schellingerhout 2004), there is strong evidence that having a support network or access to ethnic services within the neighbourhood can compensate for the lack of certain skills. Several interviewees, especially Moroccans, appeared to be remarkably well informed and resourceful in seeking additional welfare support. At the same time, some older adults had been more reluctant to rely on public assistance during their life course, but rather sought other means to support themselves. This 68-year-old
Surinamese woman tried to re-migrate after she lost her job. She explained:

[In Surinam] you don't have to take account of welfare agencies. It was the first time in my life that I had to deal with the GAK [benefit agency]. It felt very uncomfortable to enter that building to claim benefits. Because I had worked all my life, it was...I don't know how to describe it... with trembling knees I went inside. (...) I was treated like a Surinamese who thinks this is a land of milk and honey. That woman didn't know my background, but I was immediately marked as lazy.

To understand the relationship between different categories of older adults and the welfare state, it is important to refer to the differences in life histories. The point of reference for older migrants is more recent than for native born older adults. Many older migrants entered the Netherlands during an era when the classical welfare state was flourishing, but are nowadays affected by wide-reaching welfare state reforms and increased financial difficulties arising from the global economic crisis. Particular discontent about high tax rates and increasing costs for health care, housing, parking and groceries was voiced by a 61-year-old Moroccan woman:

Since 2004 life has become much harder. For some vegetables you already pay twenty Euros. For a few things, you pay an enormous amount of money. As a result, I can go to the market only once every two weeks. I don't have the money to go grocery shopping weekly. Life has become more expensive, but I receive less money. In the past, life was great. I really hope that the Netherlands will flourish once again. With twenty Euros you could buy a lot. Much has changed, partly due to the government, because I have less income, partly due to the stores that have increased their prices.

In comparison, having grown up in significantly less prosperous circumstances than later generations, the native Dutch older adults born before or shortly after the Second World War witnessed from its beginnings the dramatic transformation of Dutch society towards a modern welfare state, and thus had a different 
perspective on their financial and lifestyle circumstances. This is illustrated by the account of a 90-yearold native Dutch woman:

If I would receive a smaller amount, I would live on less money. You should not forget that we have grown up in a time when we did not have as much as older people have now. My sister always says: 'Oh, if mother could see us like this'.

Aside from income, household members are commonly considered an important source of support for older adults. Compared to the native Dutch and Surinamese interviewees, the Moroccan and Turkish interviewees lived in multiple person households more frequently. The relatively young age structure of Moroccans and Turks may-besides culture-partly account for ethnic variations in household composition. In some cases, household members were considered important informal caregivers, which enabled older people to live independently for longer than might otherwise be possible:

My son lives here with his wife and child. They stay here for me. They take care of me because I have functional limitations. My daughter-in-law does everything for me. She bathes me, makes my bed and goes shopping. She makes me breakfast. When I have somewhere to go she helps me get dressed. After that she does the household chores

(69-year-old Turkish woman; id45)

At the same time, evidence also suggests that not all multiple person households are equally supportive. Demanding household structures include those in which other household members, such as parents, a disabled child or partner, as well as school-going, unemployed and unmarried children, are in need of care or support. The presence of household members without an income clearly has adverse consequences for older people's living standards, because they contribute to higher household expenditure:

Dutch older people are better off. They receive the same salary, but they live alone or in pairs. I live here with my wife and a child. They pay $€ 400$ rent, I also pay €400 rent. They receive housing subsidy, me too. But I live here with three people. I have more mouths to feed.

(58-year-old Turkish man; id56)

In general, in terms of household resources, native Dutch interviewees-and to a lesser extent Surinamese-were better off than Turkish and Moroccan older adults, even after comparing these groups in the age group of 60-70 years. Older women, in particular Moroccan and Turkish women, were somewhat more disadvantaged than older men, due to gender differences in the residential and employment histories and gender relations within the household.

\section{Empirical findings 3: quality of the neighbourhood}

The evidence presented until now has described the experiences of native-born and migrant older people with respect to health and ageing and household resources. This final empirical section concerns older people's neighbourhood experiences and how these relate to processes of neighbourhood change.

All but two interviewees were housed in socially rented dwellings. With regard to housing accessibility-i.e. access to single-level homes without having to use stairs-we found better conditions for native Dutch and Surinamese older adults compared to Moroccans and Turks. This division can partly be explained by looking at the differences in the residential environments. The Moroccan and Turkish interviewees generally lived in areas with a large number of mid-rise portico homes that can only be accessed using stairs, while the residential environment of Surinamese interviewees was characterised by high rise flats with elevators. Native Dutch and Surinamese interviewees were also more likely to live in senior housing.

Overall, interviewees were rather reluctant to move. The majority was reasonably satisfied with their current dwelling. This may be a consequence of urban restructuring processes in which old dwellings have been renovated or replaced with new houses. Most Moroccans who participated in the study did not yet perceive stairs as a major obstacle. Turkish interviewees found housing accessibility more problematic. For older adults who did desire to move (irrespective of ethnicity), financial barriers, long 
waiting lists, practical concerns (including considered remigration) and the lack of availability of attractive alternatives in their desired neighbourhood prevented them from moving to their preferred dwelling. A 55-year-old Turkish woman commented on the combined effects of household characteristics and rent increases on her residential mobility:

When I moved here, I did not take the level of the dwelling into account. I could never expect that the stairs would become a problem (...). We would like to move to a dwelling on the ground floor, but the rents in Amsterdam have skyrocketed. I cannot work and my husband has taken early retirement, so it is difficult to move. We have no other choice than to stay, but the stairs pose a problem.

Although a number of interviewees shared the view that neighbourhood conditions have improved in recent years as a result of large-scale urban redevelopment projects, it also became clear that urban restructuring, in particular in the Indische buurt and the Kolenkit, has only just begun and has so far not been an unqualified success. The narratives revealed signs of social deprivation, such as unclean streets and sidewalks caused by other residents, limited contact with neighbours, vandalism, youth nuisance and crime. While many interviewees had not been recent victims of crime and did not report feeling particularly unsafe, numerous interviews yielded evidence of the impact of perceived crime on their day-to-day lives, as was evident in the account of a 78-year-old Surinamese woman:

I am not going out at night. When I do get outdoors, I always ask someone to walk with me (...). If I don't have an appointment, I do not open my door. Some people try anyway: 'Helen, I came for a visit, but you were not there...' Then I say: 'You don't listen, because if we don't have an appointment, I don't open the door for you' (...). When I go to sleep at night, I'll always do my inspection. I look through the peephole in my door. I look behind the curtains. If all is well, I'll go to sleep (...). I am not afraid outside, but I do not wear gold anymore. I wear fake jewellery. I always put my keys inside my pocket, because if they take my bag, I'll still have my keys to get inside.

Insufficient parking spaces and, more importantly, paid parking also featured prominently as characteristics of the neighbourhood that older people, irrespective of ethnicity, regarded as unfavourable. In the interviews (particularly in the Indische buurt and the Kolenkit), we came across many examples of how paid parking impacts older people's social life:

Our children do not come to visit us anymore (...). Because of this [paid parking], life has become shorter. We are visiting our family and acquaintances less and less. People are growing apart.

(67-year-old Turkish man; id47)

Although there was some variation across the study areas (with noticeably fewer local facilities in the Kolenkit than in the other neighbourhoods), many interviewees commented positively on the local availability of and access to transport, (basic) shops and medical services. For this 56-year-old Moroccan woman, the presence of nearby amenities alleviated some of the negative consequences of living in an unsuitable dwelling in a disadvantaged neighbourhood:

Although the house is old, it is much more important to me that neighbourhood facilities are close by. I can find anything. Here, I am independent. I can do my own shopping and I know where to find a doctor. I would only move if I could stay in this neighbourhood. Otherwise I would not be independent anymore.

Urban change undoubtedly divided the neighbourhood experiences of native Dutch and migrant older adults. Many native Dutch older people's descriptions about current neighbourhood characteristics pertained to interpretations of a more positive past. Particular discontent was expressed about the apparent deterioration in the quality of local amenities, as was reflected by the replacement of 'Dutch' shops:

One after the other Turkish and Moroccan shops came in the street (...). In the old days there was a bakery on the corner of the street, there were all 
kinds of shops, but now we have nothing anymore (...). Butchers and greengrocers, that's all we have left. I don't buy there (...).

(79-year-old native Dutch woman; id63)

The view of being increasingly surrounded by younger neighbours who are at work during the day and by migrants with whom social contact remains superficial due to cultural differences and language barriers also featured in many interviews as a negative point. A 65-year-old native Dutch woman commented on the impact of population change on the quality of her social relationships and her sense of attachment to the local community:

(...) People don't interact anymore. I hate it that behind the counters of the Albert Heijn [supermarket] they only speak Moroccan and Turkish. Then I feel out of place in my own country and in my own neighbourhood (...).

For older migrants, however, the consequences of such profound urban change clearly had a more positive outcome, at least if they lived in residential domains in which their own group is dominant. The presence of family and other members of a similar ethnic origin, and having access to ethnic amenities and meeting places, was a prominent feature that contrasted the accounts of older migrants about their neighbourhoods with those of native Dutch older people. Some interviewees described how the availability of care practitioners who spoke their native language facilitated their health care use. Their local shopping district, as a place where they could buy products from their country of origin and encounter acquaintances, also played a key role in older migrants' neighbourhood experiences and provided them with a sense of belonging:

When I am in the Javastraat, it feels like I am walking through a Moroccan or Turkish market. I feel good about it, because it makes me feel at home and because I can find basically everything I need.

$$
\text { (61-year-old Moroccan man; id8) }
$$

The comment of a 62-year-old Surinamese woman in the Bijlmer corresponds with the experiences of Moroccan and Turkish interviewees in the Indische buurt and the Kolenkit:
It is very pleasant to live in South East, if only because of the markets where I can buy all kinds of Surinamese products. This alone is a reason for me to continue living here. And of course, many Surinamese live in the Bijlmer. This gives me the opportunity to meet people with a similar ethnic background with whom I can chat.

In the Indische buurt, where the Surinamese population forms a minority, the experiences of some Surinamese older migrants were, however, more in line with the experiences of native Dutch older adults:

Several foreigners came to live here. You can barely count them. All Dutch people left the Javastraat (...). There are not many Surinamese shops in the Javastraat anymore. There is only one Surinamese-Chinese shop left. There used to be tropical shops where you could buy Surinamese vegetables.

(56-year-old Surinamese man; id29)

With respect to the quality of the neighbourhood, native Dutch older adults appeared to experience more negative effects of neighbourhood change than older migrants. The same conclusion can be formulated after adjusting for age differences.

\section{Conclusion and discussion}

In this paper we aimed to explore whether different groups of older non-Western migrants living in deprived urban neighbourhoods experience similar or different levels of multiple disadvantage compared to their native Dutch counterparts, and to analyse how multiple disadvantage can be understood in relation to life and residential histories and neighbourhood changes. In the literature, three dimensions of multiple disadvantage are distinguished: functional dependencies at the individual level, resources at the household level and the adequacy of the physical and social environment at the neighbourhood level (Deeg 2002; Scharf et al. 2005a; b; Soldo and Longino 1988; Van der Meer et al. 2008a). It is commonly assumed that older non-Western migrants have a higher risk of experiencing multiple forms of disadvantage than native older adults (Warnes et al. 2004), but research into the life and urban conditions of low-income older 
migrants and socioeconomically similar native Dutch older adults living in deprived neighbourhoods in Amsterdam has revealed that the empirical reality is more complex. All categories of low-income older adults experienced certain levels of disadvantage, though there were some variations across the dimensions. These variations can be understood in relation to differences in life and residential history and neighbourhood change.

As the native Dutch older adults in this study were more often aged 80 years and older compared with the older migrants in the study, chronic illnesses caused limitations in the performance of daily activities more often for native Dutch older adults than for older migrants. However, the results of this study might suggest that older migrants (Moroccans and Turks in particular) experience health problems and related functional limitations at a younger age than native Dutch older adults as a result of exposure to unhealthy working conditions during the life course, the stressful experience of living in a foreign country, a lack of coping skills, environmental changes and cultural forces that prescribe how people respond to age and ageing.

With respect to the household dimension, native Dutch interviewees were somewhat better off than Moroccan and Turkish older migrants, while Surinamese older adults generally held an intermediate position. The differences can be understood in relation to differences in life histories. Differences in financial resources were most obviously caused by the fact that the older migrants had not lived continuously in the Netherlands and were therefore not entitled to a full state old-age pension. Additionally, Moroccan and Turkish interviewees commonly had higher household expenditures related to culture-specific expenses and their relatively large households. Although household members are supposed to act as resources enabling older adults to retain their independence, this study suggests that instead of providing care for the interviewed older adults, in some cases household members are rather in need of care themselves; this was the case for Turkish and Moroccan older people in particular.

One might suggest that the variation between groups is the result of a skewed age distribution and skewed gender profiles within different groups-with the native Dutch and Surinamese sample being older and represented by more females. However, a comparison of identical age groups of older people aged 60-70 years hints at the suggestion that native Dutch and Surinamese older adults are indeed more often living alone, are financially better off and are somewhat more positive about their health and functional abilities than the Turkish and Moroccan interviewees. Older women appear to be somewhat more disadvantaged than older men, which is intimately connected to differential life course trajectories. For many older women, and for Moroccan and Turkish women in particular, childrearing had constrained opportunities for paid employment dramatically. Most Moroccan and Turkish women came to the Netherlands in a process of family reunification or family formation; their main task was to stay at home to care for children and the household. Accordingly, they had received limited education and were less likely to have learned the Dutch language or obtain a driving license, which increased their risk of dependency and social exclusion. This is in contrast to the experiences of Surinamese older women for whom it was more common to look after themselves and their children without being dependent on a partner. Consequently, levels of education and labour market participation were relatively high among Surinamese older women compared to Moroccan and Turkish older women. All older Moroccan and Turkish men in the research sample were married and therefore had a spouse for companionship, and for domestic service support or care when their health and mobility declined. In comparison, Moroccan and Turkish older women were less often married and less likely to remarry after divorce or the death of a spouse. Moreover, traditional gender roles more often bring older Moroccan and Turkish women than their male counterparts into the role of carer for the household, their partner, children or family members. Thus, adequate support from their spouses is not necessarily something that married older women can rely on.

At the neighbourhood dimension, we found a better quality of dwelling for native Dutch and Surinamese interviewees compared to Moroccan and Turkish older adults. However, Dutch older adults did experience the negative effects of neighbourhood deprivation more often. Processes of neighbourhood change, manifest in the ethnic composition of the population and cultural character of local facilities and shops, have generated considerable advantages for migrant older people - at least for those living in 
neighbourhoods in which their own group is dominant-while for native Dutch older adults, such changes gradually alter their neighbourhoods into more demanding and exclusionary places. Neighbourhood changes thus clearly affect groups of older adults differently.

In this paper, we presented a wide array of in-depth data relating to multiple dimensions of advantage and disadvantage for older adults with different ethnic backgrounds living in three disadvantaged neighbourhoods in Amsterdam. Yet despite the rich interview data we have assembled, it is clear that we lack the detailed information and sample size necessary to pay equal attention to ethnic as well as to gender, age and neighbourhood differences. As a result, some of the outcomes only give a first clue. Although we have to be careful when generalising, the results refine common assertions suggesting that older migrants are more disadvantaged than native older adults. The results seem to support the need to address various dimensions of advantage and disadvantage in combination and encourage future researchers on cumulative advantage and disadvantage in later life to take on a life history approach that addresses both older people's life and residential histories and neighbourhood changes in their residential environment.

Furthermore, the study raises awareness of the fact that advantages for some may result in disadvantages or exclusion for others. Assuming that there are no changes in personal competence, Lawton and Nahemow's ecological model of ageing (1973) suggests that for native Dutch older adults, further neighbourhood changes may lead to an environmental press level that is greater than a person's adaption level. This is in contrast to the experiences of certain groups of older migrants of low competence for whom the abovementioned neighbourhood changes are associated with decreased levels of environmental press and increased functioning. Consequently, exploring the contrasting resources, barriers and needs experienced by different ethnic groups living in disadvantaged neighbourhoods is of vital importance to understand processes of inclusion and exclusion in later life.

In closing, the findings may have major implications for policy makers. Prevailing Dutch policy aimed at lowering levels of environmental press in deprived neighbourhoods in the cities includes large-scale urban restructuring programs. While urban restructuring may have a positive outcome for native Dutch older people, it can have negative effects on older migrants. In order to re-establish the equilibrium, societal interventions to raise older migrants' competencies are required. However, the latest developments do not point in this direction, as the Dutch welfare state is gradually evolving into a system based on selfreliance with low levels of state support. Welfare state reforms are already being felt by older migrants and are expected to have further consequences for their financial position in the near future. A policy based on the concept of a 'participation society' stimulates older adults to remain independent in their own community as long as possible. This implies that the immediate environment and older people's local social network are becoming more important. Further research is necessary to reveal how differences in vulnerability impact upon the levels of participation and sense of belonging of older adults with a low income living in deprived urban neighbourhoods. The ultimate challenge is to create an inclusive city for all older residents, migrants and native Dutch alike. In so doing, urban planners must take into account the dynamic and complex relationship between the competencies of older adults with different ethnic and cultural backgrounds and their varying environmental needs and preferences.

Acknowledgments The authors wish to acknowledge the support of the Hans Jongstra Fund. The authors would like to thank all those who contributed to this project. We are, in particular, grateful to our interviewees. This research would not have been possible without their cooperation.

Open Access This article is distributed under the terms of the Creative Commons Attribution 4.0 International License (http:// creativecommons.org/licenses/by/4.0/), which permits unrestricted use, distribution, and reproduction in any medium, provided you give appropriate credit to the original author(s) and the source, provide a link to the Creative Commons license, and indicate if changes were made.

\section{References}

Arber, S. (2006). Gender trajectories: How age and marital status influence patterns of gender inequality in later life. In S. O. Daatland \& S. Biggs (Eds.), Ageing and diversity: Multiple pathways and cultural migrations (pp. 61-76). Bristol: The Policy Press.

Baltes, P. B., \& Baltes, M. B. (1990). Successful ageing: Perspectives from the behavioral sciences. Cambridge: Cambridge University Press. 
Baltes, P. B., \& Smith, J. (2003). New frontiers in the future of aging: From successful aging of the young old to the dilemmas of the fourth age. Gerontology, 49(2), 123-135.

Beard, J. R., \& Petitot, C. (2010). Ageing and urbanization: Can cities be designed to foster active ageing? Public Health Reviews, 32(2), 427-450.

Becker, G. (2003). Meanings of place and displacement in three groups of older immigrants. Journal of Aging Studies, 17(2), 129-149.

Bernard, M., \& Scharf, T. (2007). Critical perspectives on ageing societies. In M. Bernard \& T. Scharf (Eds.), Critical perspectives on ageing societies (pp. 3-12). Bristol: The Policy Press.

Bode, C., Drossaert, C. H. C., \& Dijkstra, E. (2007). Een verkennende studie naar de eigen beleving van het ouder worden onder Turkse en Hindostaans-Surinaamse ouderen in Den Haag [An exploratory study on experiences of ageing among Turkish and Hindustani Surinamese elderly in The Hague]. Epidemiologisch Bulletin, 42(2), 26-32.

Bryman, A. (2008). Social research methods. New York: Oxford University Press.

Buffel, T., \& Phillipson, C. (2011). Experiences of place among older migrants living in inner-city neighbourhoods in Belgium and England. Diversité Urbaine, 11(1), 13-38.

Buffel, T., Phillipson, C., \& Scharf, T. (2012). Ageing in urban environments: Developing 'age-friendly' cities. Critical Social Policy, 32(4), 517-597.

Buffel, T., Phillipson, C., \& Scharf, T. (2013). Experiences of neighbourhood exclusion and inclusion among older people living in deprived inner-city areas in Belgium and England. Ageing and Society, 33(1), 89-109.

Bulatao, R. A., \& Anderson, N. B. (Eds.). (2004). Understanding racial and ethnic differences in health in late life: A research agenda. Panel on Race, Ethnicity, and Health in Later Life. Washingon, D.C.: National Academies Press.

Burholt, V. (2004). The settlement patterns and residential histories of older Gujaratis, Punjabis and Sylhetis in Birmingham, England. Ageing and Society, 24(3), 383-409.

Burns, V. F., Lavoie, J-P., \& Rose, D. (2012). Revisiting the role of neighbourhood change in social exclusion and inclusion of older people. Journal of Aging Research, 2012, 1-12

Clarke, P., \& Nieuwenhuijsen, E. R. (2009). Environments for healthy ageing: A critical review. Maturitas, 64(1), 14-19.

Crampton, A. (2009). Global aging: emerging challenges. Pardee Paper Series 6. Boston, MA: Boston University.

Dagevos, J. (2001). De leefsituatie van allochtone ouderen in Nederland: Stand van zaken, ontwikkelingen en informatielacunes [The life situation of allochtonous elderly in the Netherlands. State-of-the-art, developments and information gaps]. Den Haag: Sociaal en Cultureel Planbureau.

Daley, C., Gubb, J., Clarke, E., \& Bidgood, E. (2013). Healthcare systems: The Netherlands. Resource document. Civitas. http://civitas.org.uk/nhs/download/netherlands.pdf. Accessed Oct 2014.

Dannefer, D. (1987). Aging as intracohort differentiation: Accentuation, the Matthew effect, and the life course. Sociological Forum, 2(2), 211-236.

Dannefer, D., \& Uhlenberg, P. (1999). Paths of the life course: A typology. In V. L. Bengtson \& K. W. Schaie (Eds.),
Handbook of theories of aging (pp. 306-326). New York: Springer Publishing.

De Jong Gierveld, J., De Valk, H., \& Blommesteijn, M. (2002). Living arrangements of older persons and family support in more developed countries. Population Bulletin of the United Nations, 42-43(1), 193-217.

Deding, M., Fridberg, T., \& Jakobsen, V. (2008). Non-response in a survey among immigrants in Denmark. Survey Research Methods, 2(3), 107-121.

Deeg, D. J. H. (2002). Ouder worden, een kwetsbaar succes [Ageing, a vulnerable success]. Amsterdam: Vrije Universiteit.

Deeg, D. J. H., \& Thomése, G. C. F. (2005). Discrepancies between personal income and neighbourhood status: Effects on physical and mental health. European Journal of Ageing, 2(2), 98-108.

Denktaş, S. (2011). Health and health care use of elderly immigrants in the Netherlands: A comparative study. Rotterdam: Erasmus University Rotterdam, Ph.D. thesis.

Dignum, K., \& Yin Kan, S. (2014). Wonen in Amsterdam 2013: Stand van zaken [Living in Amsterdam 2013: State of affairs]. Amsterdam: Gemeente.

Dijkstra, E. (2006). Oud worden in Nederland. Een onderzoek naar de beleving van het ouder worden en de gevoelens van eenzaamheid onder allochtone ouderen [Growing old in the Netherlands. A study on the perception of ageing and feelings of loneliness among older migrants]. Den Haag: afstudeerscriptie Universiteit Twente.

ERA-AGE (European Research Area in Ageing). (2007). Report of the fifth meeting of the European Forum. Paris, 26-27th November 2007. Resource document. http://era-age.group. shef.ac.uk/assets/files/FORUM\%205\%20report\%20-\%20 November\%202007.pdf. Accessed Apr 2015.

European Union. (2013). Your social security rights in the Netherlands. Resource document. European Commission. http://ec.europa.eu/employment_social/empl_portal/SSRinEU/ Your\%20social\%20security\%20rights\%20in\%20Netherlands_ en.pdf. Accessed Apr 2015.

Fiscella, K., \& Williams, D. R. (2004). Health disparities based on socioeconomic inequities: Implications for urban health care. Academic Medicine, 79(12), 1139-1147.

Grundy, E. (2006). Ageing and vulnerable elderly people: European perspectives. Ageing and Society, 26(1), $105-134$.

Hansen, R. (2003). Migration to Europe since 1945: Its history and its lessons. The Political Quarterly, 74(1), 25-38.

Katz, S. (1983). Assessing self-maintenance: Activities of daily living, mobility and instrumental activities of daily living. Journal of the American Geriatric Society, 31(12), 721-727.

Knoops, K., \& Van den Brakel, M. (2010). Rijke mensen leven lang en gezond: Inkomensgerelateerde verschillen in gezonde levensverwachting [Rich people live long and healthy: Income related differences in healthy life expectancy]. Tijdschrift voor Gezondheidswetenschappen, 88(1), 17-24.

Kullberg, J. (1997). From waiting lists to adverts: The allocation of social rental dwellings in the Netherlands. Housing Studies, 12(3), 393-403.

Lager, D., Van Hoven, B., \& Huigen, P. (2013). Dealing with change in old age: Negotiating working-class belonging in 
a neighbourhood in the process or urban renewal in the Netherlands. Geoforum, 50(2013), 54-61.

Lamers, A., De Regt, A., \& De Vries, M. (1993). Turkse en Marokkaanse ouderen in Nederland. Een kwalitatief onderzoek naar wensen en verwachtingen ten aanzien van de oude dag [Turkish and Moroccan older people in the Netherlands. A qualitative research on wishes and expectations of old age]. Amsterdam: Universiteit van Amsterdam.

Lawton, M. P. (1982). Competence, environmental press, and the adaptation of older people. In M. P. Lawton, P. G. Windley, \& T. O. Byerts (Eds.), Aging and the environment (pp. 33-59). New York: Springer Publishing Company.

Lawton, M. P. (1990). Residential environment and self-directedness among older people. American Psychologist, 45(5), 638-640.

Lawton, M. P., \& Nahemow, L. (1973). Ecology and the aging process. In C. Eisdorfer \& M. P. Lawton (Eds.), The psychology of adult development and aging (pp. 619-674). Washington, DC: American Psychological Association.

Ministerie VROM/WWI. (2009). Rangorde krachtwijken. Resource document http://nicis.platform31.n1/Wat_doen_ wij/Verspreiding/Docbank/Wonen/Wijken/Wijkenaanpak/ Minister_van_der_Laan_maakt_rangorde_krachtwijken_ bekend. Accessed Oct 2014.

Musterd, S., \& Deurloo, R. (2002). Unstable immigrant concentrations in Amsterdam: Spatial segregation and integration of newcomers. Housing Studies, 17(3), 487-503.

Musterd, S., \& Van Kempen, R. (2007). Trapped or on the springboard? Housing careers in large housing estates in European cities. Journal of Urban Affairs, 29(3), 311-329.

Musterd, S., \& Van Kempen, R. (2009). Segregation and housing of minority ethnic groups in Western European cities. Tijdschrift voor Economische en Sociale Geografie, 100(4), 559-566.

Naegele, G., \& Walker, A. (2008). Social protection: Incomes, poverty and the reform of pension systems. In J. Bond, S. Peache, F. Dittmann-Kohli, \& G. Westerhof (Eds.), Ageing in society: European perspectives on gerontology (pp. 142-166). London: Sage Publications.

Nitsche, B., \& Suijker, F. (2003). Allochtone ouderen en wonen [Older migrants and Housing]. Utrecht: FORUM, Instituut voor Multiculturele Ontwikkeling/NIZW, Nederlands Instituut voor Zorg en Welzijn.

O'Rand, A. M. (2006). Stratification and the life course: Life course capital, life course risks, and social inequality. In R. H. Binstock \& L. K. George (Eds.), Handbook of aging and the social sciences (pp. 145-162). San Diego: Academic Press.

Phillipson, C. (2007). The 'elected' and the 'excluded': Sociological perspectives on the experience of place and community in old age. Ageing and Society, 27(3), 321-342.

Phillipson, C. (2010). Ageing and urban societies: Growing old in the 'century of the city'. In D. Dannefer \& C. Phillipson (Eds.), The sage handbook of social gerontology (pp. 597-606). London: Sage Publications.

Pudaric, S., Sundquist, J., \& Johansson, S. (1998). Impaired mobility and impaired working capacity among foreign born people and native born Swedes. Journal of Epidemiology and Community Health, 52(1), 34-40.

Razin, A., \& Sadka, E. (2000). Unskilled migration: A burden or a boon for the welfare state? Scandinavian Journal of Economics, 102(3), 463-479.
Reinprecht, C. (2006). Nach der Gastarbeit; Prekäres Altern in der Einwanderungsgesellschaft [After the guest worker phase: Precarious ageing in an immigration society]. Vienna: Braumüller.

Robert, S. A., \& Ruel, E. (2006). Racial segregation and health disparities between black and white older adults. Journal of Gerontology Series B-Psychological Sciences and Social Sciences, 61(4), 203-211.

Rowe, J. W., \& Kahn, R. L. (1998). Successful aging. New York: Pantheon Books.

Scharf, T., \& Bartlam, B. (2006). Rural disadvantage: Quality of life and disadvantage amongst older people-a pilot study. London: Commission for Rural Communities.

Scharf, T., Phillipson, C., Kingston, P., \& Smith, A. E. (2001). Social exclusion and older people: Exploring the connections. Education and Ageing, 16(3), 303-320.

Scharf, T., Phillipson, C., \& Smith, A. E. (2004). Poverty and social exclusion: Growing older in deprived urban neighbourhoods. In A. Walker \& C. H. Hennessy (Eds.), Growing older: Quality of life in old age (pp. 81-106). Maidenhead: Open University Press.

Scharf, T., Phillipson, C., \& Smith, A. E. (2005a). Multiple exclusion and quality of life amongst excluded older people in disadvantaged neighbourhoods. London: Report Office of the Deputy Prime Minister.

Scharf, T., Phillipson, C., \& Smith, A. E. (2005b). Social exclusion of older people in deprived urban communities of England. European Journal of Ageing, 2(2), 76-87.

Schellingerhout, R. (Ed.). (2004). Gezondheid en welzijn van allochtone ouderen [Health and well-being of older migrants]. Den Haag: Sociaal en Cultureel Planbureau.

Schenk, N., Dykstra, P., Maas, I., \& Van Gaalen, R. (2013). Older adults' networks and public care receipt: Do partners and adult children substitute for unskilled public care? Ageing and Society, 34(10), 1711-1729.

Schmeets, H. (2004). Respons van eerste generatie allochtonen in het POLS [Response of first generation immigrants in POLS]. Bevolkingstrends, 2004(4), 92-97.

Soldo, B. J., \& Longino, C. F. (1988). Social and physical environments for the vulnerable aged. In Committee on an Aging Society (Ed.), The social and built environment in an older society (pp. 103-133). Washington, DC: National Academy Press.

Statistics Netherlands. (2014). Data derived from Statline. Population: sex, age, origin and generation, 1 January. Resource document. http://statline.cbs.nl/Statweb/publication/?DM= SLEN\&PA $=37325$ eng $\& D 1=a \& D 2=0 \& D 3=112-120,1 \&$ D4=0\&D5=1,139,216,231\&D6=13-18\&HDR=G4,G2,T\& $\mathrm{STB}=\mathrm{G} 1, \mathrm{G} 5, \mathrm{G} 3 \& \mathrm{VW}=\mathrm{T}$. Accessed Apr 2015.

Street, D. A. (2007). Sociological approaches to understanding age and aging. In J. A. Blackburn \& C. N. Dulmus (Eds.), Handbook of gerontology: Evidence-based approaches to theory, practice, and policy (pp. 142-170). Hoboken, New Jersey: Wiley.

United Nations. (2008). World urbanization prospects: The 2007 revision. New York: Department of Economic and Social Affairs, Population Division.

Van Amersfoort, H., \& Cortie, C. (1996). Social polarisation in a welfare state? Immigrants in the Amsterdam region. New Community, 22(4), 671-687. 
Van der Greft, S., Musterd, S., \& Thissen, F. (2014). Residential dynamics and neighbourhood conditions of older migrants and native Dutch older adults in Amsterdam, the Netherlands. Ageing and Society,. doi:10.1017/S0144686X 14001159.

Van der Meer, M., Fortuijn, J. D., \& Thissen, F. (2008a). Vulnerability and environmental stress of older adults in deprived neighbourhoods in the Netherlands. Tijdschrift voor Economische en Sociale Geografie, 99(1), 53-64.

Van der Meer, M., Thissen, F., Fortuijn, J. D., Van der Tak, I., \& Van der Wouw, D. (2008b). De sociale draagkracht van dorpen in Borsele; Leefbaarheid, sociale cohesie en community care in kleine dorpen [Social resilience of villages in Borsele: liveability, social cohesion and community care in small villages]. Amsterdam: AMIDSt - UvA.

Van Oorschot, W. J. H. (2006). The Dutch welfare state: Recent trends and challenges in historical perspective. European Journal of Social Security, 8(1), 57-76.

Van Tilburg, T. (2005). Gesloten uitbreiding: Sociaal kapitaal in de derde en vierde levensfase [Closed expansion: Social capital in the third and fourth phase of life]. Amsterdam: Vrije Universiteit.

Vandevyvere, W., \& Zenthöfer, A. (2012). The housing market in the Netherlands. Economic Papers 457. European Commission, Brussels.

Verhoeven, A., Kooiker, S., \& Van Campen, J. (2011). Perspectieven van ouderen op kwetsbaarheid en kwaliteit van leven [Perspectives of older adults on vulnerability and quality of life]. In C. Van Campen (Ed.), Kwetsbare Ouderen [Vulnerable Older Adults]. Sociaal en Cultureel Planbureau: Den Haag.
Waite, L. J., \& Hugfies, M. E. (1999). At risk on the cusp of old age: Living arrangements and functional status among black, white and Hispanic adults. Journals of Gerontology. Series B, Psychological Sciences and Social Sciences, 54(3), 136-144.

Warnes, A. M. (1990). Geographical questions in gerontology: Needed directions for research. Progress in Human Geography, 14(1), 24-56.

Warnes, A. M., Friedrich, L., Kellaher, L., \& Torres, S. (2004). The diversity and welfare of older migrants in Europe. Ageing and Society, 24(3), 307-326.

Warnes, A. M., \& Williams, A. (2006). Older migrants in Europe: A new focus for migration studies. Journal of Ethnic and Migration Studies, 32(8), 1257-1281.

Whelan, C. T., Maître, B., \& Nolan, B. (2007). Multiple deprivation and multiple disadvantage in Ireland: $A n$ analysis of EU-SILC. Policy Research Series 61.

World Health Organisation (WHO). (2007). Global age-friendly cities: A guide. Geneva: WHO Press.

World Health Organisation (WHO). (2014). The determinants of health. Resource document. http://www.who.int/hia/ evidence/doh/en/. Accessed Oct 2014.

Zaidi, A. (2010). Poverty risks for older people in EU countries-An update. Policy Brief Series. Vienna: European Centre for Social Welfare Policy and Research.

Zorlu, A. (2011). Immigrant participation in welfare benefits in the Netherlands. IZA Discussion Papers 6128, Institute for the Study of Labor (IZA). 